\title{
Residential Real Estate in Europe: An Exploration of Common Risk Factors
}

\author{
Elena Druica, Calin Valsan, Rodica Ianole ${ }^{1}$
}

\begin{abstract}
We conduct an exploratory analysis using proxy measures of cross-sectional returns and rental yields in residential real estate. Asset pricing models predict that expected returns should exhibit some sensitivity to one or several fundamental variables that represent a common source of undiversifiable risk. Residential real estate, just like works of art and collectibles, is unique because it represents both an investment vehicle and a durable consumption good. Its pricing and returns should thus reflect both the benefits from portfolio diversification and the effect of supply and demand. In this paper, we investigate the variation in proxy returns and proxy rental yields across 34 major European cities, using a handful of independent variables that should account for the influence of market risk, inflation, and liquidity. In spite of obvious limitations stemming from our sample, we find that the explanatory power of our model is unusually high for a cross-sectional data analysis. Some of our findings concur with other studies showing that in spite of strong segmentation, real estate markets respond to the same structural risk factors. A good portion of our results, however, is hard to explain and interpret. Either we need to take into account cultural differences between Eastern and Western Europe as part of a behavioral approach, or we have to concede that we have been misled by the mismatch in the level of aggregation and the crude estimation of the dependent variables.
\end{abstract}

Key words: Residential real estate, returns, yields, behavior economics, Eastern Europe

JEL Classification: P50, R15, R31, E21, G02, G10

Received: 2 June 2015 / Accepted: 24 November 2015 / Published: 21 December 2015

\section{Introduction}

We conduct an exploratory analysis using proxy measures of cross-sectional returns and rental yields in residential real estate. More specifically, we investigate the variation in proxy returns and proxy rental yields across 34 major European cities, using a handful of independent variables that should account for the influence of market risk, inflation, and liquidity. Although exploratory in nature, our model draws heavily on existing mainstream economic research in the area of asset pricing.

\footnotetext{
${ }^{1}$ E.D. and R.I. affilated with: Faculty of Business and Administration, University of Bucharest, elena.druica@faa.unibuc.ro, rodica.ianole@faa.unibuc.ro (correspondent author); C.V. affiliated with: Williams School of Business, Bishop's University, cvalsan@ubishops.ca.
}

(c) 2015 by the authors; licensee Review of Economic Perspectives / Národohospodárský obzor, Masaryk University, Faculty of Economics and Administration, Brno, Czech Republic. This article is an open access article distributed under the terms and conditions of the Creative Commons Attribution 3.0 license, Attribution - Non Commercial - No Derivatives. 
The residential real estate market has always been an important part of the economy and represents a significant chunk of the total wealth of any given country. Kullmann (2001) suggests that the aggregate value of real estate is of the same order of magnitude as the total value of all exchange-traded stocks in countries with well-developed financial markets and a high degree of securitization, such as the United States and the United Kingdom. Goetzmann and Dhar (2005) claim that the riskiness of real estate is perceived to be somewhere in between that of bonds and common stock. Investors perceive it as a hedge against inflation and liquidity risk. It is acknowledged, however, that real estate, in particular residential real estate, represents a more complex picture than that of a simple investment vehicle to be added to a portfolio of well-diversified assets, as it is often depicted in the financial literature.

The complexity of the residential market is given by the interplay between homeowners and investors. To homeowners, real estate represents an intrinsic consumption utility as well as a tangible investment vehicle, seen as protection against the vagaries of interest rates, stock returns, and financial markets in general. Price and returns should thus be determined, partly as the result of supply and demand, and partly as suggested by multifactor return generating models. To investors and landlords, residential real estate represents all but a pure investment vehicle that has significant systematic risk. In this case, prices and returns should fully reflect the benefit from diversification. Studies find that indeed the empirical evidence of a significantly positive risk premium for real estate risk is strong, and that residential real estate risk is priced accordingly in the crosssection of returns on portfolios. [Kullmann (2001)].

It is notoriously difficult to conduct extensive studies on real estate returns because its two main components are hard to observe and measure. Just like the return on common stock, return on real estate has a component represented by capital appreciation, and another one represented by the cash flow generated from operations. Dividend yields and capital gain yields on exchange-traded stocks are closely monitored, scrutinized and recorded with precision. Statistics on home price indices are more difficult to come by and are less comprehensive. Rents, however, are largely ignored because the available data is too sketchy. As a consequence, most attempts to measure returns to residential real estate overlook an important element, and result in either an over- or underestimation.

In this study, we deviate somewhat from the traditional estimation of returns to real estate. We focus solely on residential real estate. We consider the total return, but we also use two proxy measures of rental yields as stand-alone variables. We develop a proxy measure of the rental yield by dividing the annual income of the property (usually in form of the rent, minus the associated expenses for operating the property) by its buying price. Two main categories of use for the yield are discussed in literature: as a valuation tool or as a benchmark for identifying bubbles (Hungria-Garcia et al., 2004). Dubben and Sayce (1991) suggest that the main factors determining the yield (not particularized for residential properties) consist of expectations for rental growth, quality of investment, development potential, risk, and comparative returns.

In theory, the particularities of the residential real estate market are not always taken into consideration. Goods in this market are highly heterogeneous, immovable, and durable in the very long run. This makes their supply relatively rigid in the short run 
(given the time, effort and financial resources to build a house/real estate complex) and puts an emphasis on demand as an influencing force for the yield. More precisely, a high demand for housing will lower the yield, with immediate consequences on the size of the risk premium (Ball et al., 1998). An exemplification is provided by Hargreaves (2005) in the case of Australia, where the high value of net yields of apartments is believed to be due to the offers made by developers, consisting in short term rental guarantees as a sales inducement.

\section{Returns and yields: Theoretical considerations}

In general, required returns are of the following form:

Required return $=$ Risk-free rate + Time preference premium + Pure risk premium + Liquidity premium + Inflation premium

The quintessential investment is defined as an act of postponing current consumption in favor of future consumption, hence the time preference premium. In a world of absolute certainty, no inflation, and maximum liquidity, investments would still command positive returns because delaying current consumption saddles the economic agent with a hedonic cost.

It has already been argued that real estate involves a special type of asset representing both an investment vehicle and a durable consumption good. Buying real estate generates no disutility because the homeowner need not postpone current consumption in order to invest. Postponing consumption is merely a choice made by landlords. Hence, the return on real estate in general should not require a time preference premium, as long as the market is dominated by homeowners. Returns to real estate should generally be lower than other investments with similar market sensitivity to the same return generating factors. Nevertheless, as with other assets, returns to real estate should exhibit sensitivity to factors such as systematic risk, inflation, and liquidity [Ross (1976)]:

Required return $=$ Risk-free rate + Pure risk premium + Inflation premium + Liquidity premium

This argument is somewhat softened in the presence of rental companies and other types of landlords. In a market dominated by homeowners, one should see the time preference premium vanish, while he opposite should hold true when homeowners represent a minority. The realized returns to most forms of investments have in general two components: current yield, and capital appreciation. If follows that returns to real estate exhibits a component that measures the effect of current operations, that is renting, and the effect of price changes in the value of the property.

\section{Observed return to real estate $=$ Rental yields + Property appreciation}

In the formulation above, rental yields and price appreciation should be contemporaneous. In this paper we focus on two variables that represent surrogates for real estate returns in a cross-sectional analysis: proxy total returns, and proxy rental yields. Since complete returns series are not readily available, we attempt to reconstruct them by adding the previous year's price appreciation to current proxy rental yields. We posit 
that since rents take a year or so to respond to changes in fundamentals, they can be considered nearly contemporaneous to price changes.

Over relatively short periods of time, the appreciation or depreciation in the price of the property tends to be relatively small, in all but a few cases when the market is headed for a spectacular upturn or a severe downturn, such as the ones experienced before and during the subprime meltdown of 2007 and 2008. This is unlike the stock market, where the price of shares can swing significantly from one week to another, without wandering outside the limits of "normality." It goes without saying that, just like property prices, rental yields are also subject to the influence of market risk, liquidity, and inflation.

We use cross-sectional data to estimate the sensitivity of proxy returns and proxy rental yields to several factors that asset pricing models consider as highly influential. In other words, we explore the relation between proxy measures of returns and rent yields on the one hand, and approximate measures of market risk, inflation, and liquidity, on the other hand. We concede that our methodology is not sophisticated enough, and our data is too sketchy and problematic to meet the standard for testing the form of the return generating process in the real estate market, therefore we settle for an exploratory analysis. We merely wonder to what extent the cross-sectional variation in realized proxy returns and proxy rental yields (as a component part of these returns) can be explained by the crosssectional variation in several factors that should be associated with the return generation process, according to existing asset pricing models [Roll and Ross (1980), Burmeister and Kent (1986)].

The variables selected as dependent are as follows: size of the real estate property, GDP/capita, the Consumer Price Index, population, round trip transaction costs, ownership rates, changes in prices over the previous one- and five years, and tax on rental income. One can argue that changes in GDP per capita account for market risk, changes in the Consumer Price Index account for inflation, and changes in population and transaction costs account for liquidity. Since our data involves distinct and potentially segmented real estate markets, we also need to control for the effect of taxes on rental income.

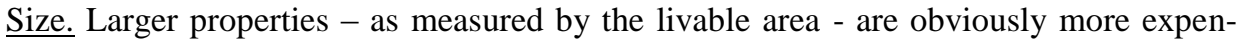
sive and command higher prices and higher rents. It is common knowledge among real estate agents, however, that larger properties tend to take longer to sell, and are the first ones to drop in value when the economy is in the doldrums. The subprime meltdown of 2007 and the economic crisis that ensued are cases in point. On the other hand, smaller and more modest properties are more likely to keep their value because there is a stronger and more stable demand from lower income and middle-class individuals. There is little need to point out that there are far more lower income and middle-class individuals than there are millionaires. Regardless of the predicament in which the economy finds itself, people will always need a roof above their heads. Moreover, in dire times, the relatively inelastic demand for affordable housing is swelled by those downgrading their lifestyle.

There is enough evidence to support the contention that larger properties, exhibit larger volatility in their market values, and there is no reason to expect that rents yields would be any different. One can argue that higher return volatility in itself is not a sufficient 
reason to command a positive risk premium when a rational market should only price systematic rather than diversifiable risk. Nevertheless, one can reasonably suspect that size might act as a catalyst for the influence of the GDP, a fundamental factor responsible for the documented common effects across international real estate markets. Whether size alone matters or not, we expect that the sign of the coefficients between total returns and size, and between rental yields and size to have the same sign as the coefficients between total returns and GDP, and between rent yields and GDP.

GDP per capita. There seems to be a general consensus in the financial literature that GDP per capita approximates a fundamental market factor and accounts for systematic risk across countries and continents. Bradford Case, William Goetzmann, and K. Geert Rouwenhorst (1999) find that real estate is an asset local in its nature and represents a bet on fundamental economic variables and global trends in production and wealth change. While one can easily see how property prices and rents increase with the wealth of a nation, it is, however, more difficult to ascertain the direction in which rent yields would respond to changes in fundamentals, such as GDP per capita. We refrain from making a prediction about the direction of the relationship, but we nevertheless expect to see a significant regression coefficient. A significant coefficient between returns and yields, on the one hand, and GDP per capita on the other hand would confirm the results of other studies. A negative, yet significant coefficient would certainly strengthen the case for portfolio diversification, as real estate would represents a good hedge, not only against inflation, but also against major shifts in production and other market fundamentals.

The Consumer Price Index. There is little doubt that both homeowners and landlords expect residential real estate to act as a hedge against inflation, alongside other tangible assets, such as gold and silver (Goetzman and Dahr 2005). There is still some debate around the magnitude of returns to real estate, but many studies find that it is indeed a good hedge against inflation. Eicholtz finds that the average real price increase after World War Two was about 3.2 percent per annum. If we could take annual rental yields into consideration, this amount would most likely be high enough to offset the rise in consumer prices. We obviously expect a direct relationship between total returns and rental yields, on the one hand, and the Consumer Price Index on the other hand, although we also acknowledge that in the short-term, the relationship among returns, rent yields and consumer prices might be more complex than it appears. Landlords would certainly ask higher rents to compensate for inflation, but most lease contracts lock in the rent for a determined period of time, usually one year. If consumer prices rise significantly over the duration of the year, gross revenue from rents could very well fall behind maintenance costs and other expenses associated with the upkeep of the property. A majority of European countries in our sample, however, fall in a low to moderate inflation category. Most importantly, since the most are part of the European Union, and the rest aspire to become part of it, inflation has been more or less controlled everywhere since the late 1990 s.

Population. In our opinion, this variable represents a reasonable proxy for liquidity. One expects that in more populous urban centers business activity is more dynamic and vibrant, there is an abundance of better paid jobs, and properties would turn over more quickly than in smaller, more patriarchal towns or in rural areas. There are forces at play 
that would push both property prices and rents higher. Predicting the direction of the relationship might be difficult when rationalizing the interplay among landlords, homeowners and tenants, but we nevertheless expect a positive and significant coefficient.

Transaction costs. Transaction costs represent round-trip cost of buying and selling a property. We do expect to find a positive and significant relationship to total returns because transaction costs undoubtedly represent a proxy for liquidity and thus should command a positive return premium.

\section{Data}

We collected data on real estate markets across several major cities in Europe. We are well aware that there are major differences in GDP per capita, home ownership rates, taxation, and perhaps other characteristics that might set each market apart from the rest. At the same time, there is much evidence suggesting that real estate markets are quite globalized in a certain sense. Case, Goetzmann, and Rouwenhorst (1999) consider that real estate is neither a tradable good nor a fungible investment asset. In theory, one would expect changes in market values across various geographical markets to be weakly correlated, if at all. Any correlation should decrease or vanish the further properties are apart because discrepancies in their prices cannot be arbitraged away in the same manner one would arbitrage forward contracts on two geographically different markets. As the authors simply put it - "buildings from one market cannot be moved to the other."

The authors of the study find that correlations among international real estate markets are surprisingly high, in spite of a high degree of geographical market segmentation. Case, Goetzmann, and Rouwenhorst (1999) attribute a substantial amount of the correlation across various real estate markets to the effects of changes in production and level of wealth, as measured by the Gross National Product. The authors contend that real estate must be a bet on those fundamental economic variables that exhibit a high degree of correlation across countries.

The conclusion of the study is that real estate markets are indeed segmented and fundamentally local by their very nature. In spite of a high exposure to local characteristics, they are also exposed to market variables that are global in nature, and thus highly correlated across countries. Common GDP effects represent a source of common systematic risk, which is hardly surprising in the age of globalization, and thus, real estate portfolios should mitigate the risk of broad trends in global production and wealth. In a similar vein, Bond, Karolyi, and Sanders (2003) found that sensitivity to countryspecific market risk is much more significant for real estate markets in the Asia-Pacific region than for those in Europe or North America.

In total, there are 156 observations from 34 major cities in 24 European countries. The vast majority of cities are located in European Union member states, as shown in Table 1. Switzerland, Serbia, and Croatia are exceptions to be noted. Out of 24 countries, 12 are represented by former Eastern European communist countries, accounting for 64 observations. As it will be seen later, this distinction is important because real estate markets in Eastern European cities have several distinctive characteristics that set them apart, in spite of their high correlation to other real estate markets in the rest of Europe. The source of data consists of observations and measurements made publicly available 
by Global Property Guide, the World Bank, and Statista. All observations represent the latest available figures, that is for the year 2013. We have discarded observations for which data was not contemporaneous with the rest of the sample.

Sample statistics are provided in Table 2. The tax on rental income is the tax levied on the average annual income on a rental apartment/property in each the country. Global Property Guide assumes the property is personally directly owned jointly by husband and wife, there is no other income and the property has been financed with equity. Deductions consist of depreciation and capital allowances, and other costs normally paid by the landlord, such as, management charges, insurance, and fees. The tax on rental income ranges from $0 \%$ in Latvia and the United Kingdom, to almost 50\% in Switzerland. The average is about $16 \%$, which is a fairly representative figure for a large number of observations in our sample.

The livable area of the property ranges between 35 square meters for a very small apartment or studio, and 250 square meters, for larger properties, with an average of 102 square meters, and a median of 85 square meters. The Consumer Price Index ranges from a negative $0.7 \%$ in Switzerland, to a high of $28.5 \%$ in Serbia, with an average of $8.42 \%$, and a median of $7.7 \%$. The data has been gathered from the World Bank for the latest year available.

Transaction costs represent the round-trip costs of buying and re-selling a residential property including all costs (except the sale price itself). These costs are expressed as a percentage of the property value. In calculating transaction costs, Global Property Guide makes several normalizing assumptions, i.e., the property is purchased by a non-resident foreigner in the country where he/she is buying, the transaction is worth the equivalent of $\$ 250,000$, it is paid in cash, is not newly built, and is not bought from a developer or real-estate holding company. In the calculation of transaction costs are also included registration costs, real estate and legal fees, and sales and transfer taxes (excluding the Value Added Tax). In our sample, transaction costs range from a low $3.45 \%$ in Sofia, Bulgaria, to a high $21 \%$ in Brussels, Belgium. On average, the round-trip costs of buying and selling property are between $10 \%$ and $12 \%$.

The gross domestic product (GDP) per capita is the national economic output expressed in USD, divided by the population, and is estimated for the latest available year. GDP ranges from $\$ 6,354$ per capita in the case of Novi Sad in Serbia, to $\$ 84,000$ per capita in the case of Geneva, in Switzerland, with an average of $\$ 29,150$, and a median of $\$ 22,780$. Nevertheless, we are well aware that there is a mismatch in the level of aggregation of the GDP per capita - calculated for the overall country - and other variables, such as rents - which refer to properties located in major cities. One can argue, however, that any differences in the levels of GDP per capita between major cities and the rest of the country should be scalable across the 24 European countries investigated.

Home ownership rates are estimated as the share of owner-occupied dwellings of all homes. Cooperatives and NGOs are excluded. The data has been gathered from Statista.com ${ }^{1}$, for the latest year available. Home ownership rates range from $44 \%$ in Geneva and Zurich, to almost $96 \%$ in Bucharest, Romania, with an average of $74.4 \%$, and a median of $75.8 \%$. As in the case of GDP per capita, there is, however, a mismatch in the 
level of aggregation of the data. Home ownership rates are estimated at the national level, while rents and population, for example are estimated for major cities.

Proxy rental yields are estimated as the gross annual rental income after maintenance fees and other costs, but before taxes, expressed as a percentage of property purchase price. A crude proxy of after-tax proxy rental yields is obtained by subtracting taxes from proxy yields. The data includes only resale apartments and houses in excellent condition, with good facilities that have been refurbished or redecorated within the last five years (excluding newly-built properties). The lowest rental yield is $1.78 \%$ and the highest is $8.30 \%$, with an average of $4.55 \%$, and a median of $4.62 \%$. After-tax rent yields range from $1.17 \%$ to $6.83 \%$, with an average of $3.91 \%$ and a median of $3.73 \%$.

Proxy return represents the current rental yields plus the prior one-year change in real estate property prices. Obviously, this is a crude proxy of return because a) it is based on a price index estimated as an average across an entire market, and not based on individual observation of real estate properties, b) it lags rental yields by one year, and c) rental yields are also calculated as an index averaged cross a real estate market, and not as a function of individual observations.

It is not hard to see that observations from cities in the former communist countries of Eastern Europe show a similar pattern in the range of their values. A cursory analysis of the independent variables across these lines shows that Eastern Europe stands out in several important aspects. Table 3 shows that the most dramatic differences occur in changes in inflation, GDP per capita, transaction costs, and ownership rates. Rental yields also tend to be higher in Eastern Europe.

These numbers suggest that real-estate markets in Europe are segmented in more than one way. While there are unique characteristics in each European city, Eastern European cities are more dissimilar from cities in Western Europe than form each other. The particularities of Eastern European real-estate markets can be partially explained by the history of the transition from communism to free markets, and the manner in which post-communists governments endowed citizens with the only form of wealth readily available for re-allocation: residential real estate.

Table 4 shows the matrix of the correlation coefficients. Most correlation coefficients among our variables are rather low. We notice that ownership is strongly and negatively correlated with GDP per capita. This suggests that individuals in countries that are poorer tend to keep almost all of their wealth invested in real estate properties because they face high inflation and economic instability, underdeveloped capital markets, and a lack of adequate asset diversification alternatives. We also notice a moderate correlation between GDP per capita and the level of tax on rental income. In order to mitigate potential issues associated with multicollinearity, we formulate several alternative models in which the dependent variable is estimated either as gross rental, or as after-tax rental yields.

\section{Models and results}

We run two versions of the ubiquitous OLS regression model. The first version has (proxy) returns as dependent variable. Each version has four specifications: 
Returns $=$ Intercept + Area + CPI + GDP/capita + Population + Transaction costs + Tax on rental income + Five-year price change (1.)

Returns $=$ Intercept + Area $+C P I+$ GDP/capita + Population + Transaction costs + Tax on rental income + Five-year price change + DummyEE (2.),

where:

\section{Return $=$ Rental yield + One-year price change}

We take a hint from purchasing power parity studies that control for taxes, duties, levies, and transaction costs, and we calculate a relatively crude proxy for after-tax rent yield in the hope that it might streamline our regression model. Mitigation of the effects of the (moderate) correlation between tax on rental income and GDP/capita, as mentioned earlier, is another advantage of estimating after-tax values. We also include a dummy variable for Eastern Europe in two of the four regression models estimated here.

Returns $^{*}=$ Intercept + Area $+C P I+$ GDP/capita + Population + Transaction costs + Five-year price change (3.)

Returns $^{*}=$ Intercept + Area + CPI + GDP/capita + Population + Transaction costs + Five-year price change + DummyEE (4.),

where:

Return $($ after-tax $)=$ After tax rental yield + One-year price change

A summary of results is presented in Table 5. The estimated regression coefficients deliver several unexpected outcomes. The most striking one is the proportion of cross sectional variation in our dependent variable that is explained by the variation in a handful of independent variables. Our estimation method for returns and yields is rather rudimentary, there is a relative mismatch in the level of data aggregation, and our sample is very small. Yet the evidence confirms without a doubt that residential real estate markets across the European continent, in spite of their obvious segmentation, are sensitive to the same handful of common fundamental economic factors that account for wealth, inflation and liquidity.

We see a negative and significant coefficient for inflation and GDP per capita. Proxy rental yields respond to variations in economic fundamentals that represent a common source of market uncertainty across real estate markets. We know that real estate represents a hedge against inflation but one would have expected a positive coefficient. We see a negative variation in returns of 0.15 to 0.20 percentage points for every additional dollar of variation in GDP per capita. This result strengthens the case for portfolio diversification, but it is not entirely clear why the sign is negative. This result could stem from pressure on real estate property prices, pressure on rents, or a combination of the two. It is quite possible that larger increases in production and wealth puts upward pressure on real estate prices, thus reducing returns. One can speculate that the upward pressure on prices is stronger than that on rents, and that institutional and regulatory differences across market unevenly limit the ability of landlords and real estate companies to hike rents in response to changes in contemporaneous economic fundamental. We might as well deal with cities where rents can vary on a short notice, while contracts might lock in the terms of the lease for a period of one year or more in others. But while up- 
ward pressures on prices might reduce rental yields, at the same time they also tend to increase that portion of return represented by the appreciation in the market value of the property. Moreover, one can speculate that in poorer countries of Eastern Europe, a larger portion of wealth is invested in real estate, thus making it more susceptible to speculative bubbles. Last but not least, we might see the effects of the mismatch between GDP per capita (estimated for the entire country) and the other variables, such as rent and population (estimated for major cities).

The coefficient for transaction costs is negative and significant. We expected a positive sign since transaction costs, together with population, approximate liquidity. We note that when returns are estimated based on after tax rental yields, the coefficient ceases to be significant. The coefficient for population is positive and significant, and its sign is also unexpected. Since we speculated that population is a proxy for liquidity, one would have expected a negative relationship. Perhaps in larger cities the upward pressure on rents is much stronger than that on prices. Yet again, since returns have two components, an upward price pressure might reduce one component, while increasing the other. Perhaps the manner in which we estimated returns does not capture this effect, due to the time lag between price appreciation and rental yields.

The coefficient of the five-year change in prices is positive and significant, suggesting that returns have medium-term momentum across all markets. This finding strengthens even more the evidence for common structural effects across European real-estate markets. The dummy variable for Eastern Europe is, however, only marginally significant in this model specification.

Next, we turn to the second version of our model. This time we use proxy rental yields as the dependent variable. This version also has four similar specifications:

Yield $=$ Intercept + Area $+C P I+$ GDP/capita + Population + Transaction costs + Tax on rental income + One-year price change + Five-year price change (5.)

Yield $=$ Intercept + Area $+C P I+$ GDP/capita + Population + Transaction costs + Tax on rental income + One-year price change + Five-year price change + Dummy for Eastern Europe (6.)

Yield $^{*}=$ Intercept + Area $+C P I+$ GDP/capita + Population + Transaction costs + One-year price change + Five-year price change (7.)

Yield $^{*}=$ Intercept + Area $+C P I+$ GDP/capita + Population + Transaction costs + One-year price change + Five-year price change + Dummy for Eastern Europe (8.),

where Yield $*=$ Yield $(1-$ Tax on rental income)

Regression results are presented in Table 6. Again, we are pleasantly surprised by how good a fit the model really is. We are still able to explain up to $70 \%$ of the variation in the dependent variable, which suggests that it is perhaps mostly the sensitivity of proxy rental yields that drives our cross-sectional results.

The estimated regression coefficients deliver even more unexpected results, the most striking of which is the negative and significant relationship between proxy rental yields and the livable size of the real estate property, measured in square meters. Every additional square meter of livable space results in a 0.006 percentage point decrease in after- 
tax rental yields. We have argued that larger properties tend to be riskier because they exhibit a larger variability in prices and yields. Regardless of whether size represents a source of systematic risk, we nevertheless expected a positive coefficient.

The coefficient for inflation is not significant anymore when we specify proxy after-tax yields as dependent variable. We expected proxy rental yields, which represent a significant component of returns, to exhibit some sensitivity to variations in consumer prices across markets. After all, rents enter the calculation of the Consumer Price Index. This is even more puzzling because the data on inflation lags on year behind the data on rental yields, giving ample time to rents to change subsequently to changes in consumer prices. While over long periods of time, returns respond to changes in inflation, shortterm rental yields do not appear to respond to variations in inflation across real estate markets. Again, we speculate that we must deal with some cities in which rents can vary on a short notice, while in others contracts might lock in the terms of the lease for a period of one year or more.

The estimated coefficient for population is not significant anymore. Population was included in the regression analysis to control for the effect of liquidity, and we are somewhat surprised to see its lack of significance. It is possible that we might have inadvertently introduced a selection bias in our sample. All cities are large and very large, whether in France, UK, Germany, Croatia, Bulgaria, or Romania. Although they range in size from under half a million to over seven million inhabitants, they are essentially big cities. It is possible that beyond a certain threshold, a more numerous population would not matter anymore. We might have probably seen a more significant crosssectional variation in yields driven by population had we included in our sample smaller towns and rural areas. And perhaps, there is a much stronger upwards pressure on property prices than on rents in more populous cities, as hypothesized earlier.

The coefficient of GDP per capita is significant, but again negative, with the exception of one instance. Cities and countries with the biggest increase in production are more likely to see lower relative rental yields. Again, we hypothesize that this result might have something to do with the effect of uneven pressures on prices compared to rents, and with a higher probability of real estate bubbles in countries with the largest potential for swings in GDP per capita, that is, the poorer countries of Eastern Europe. This speculation appears reinforced by the significance of the dummy coefficients for Eastern Europe.

An alternative and less desirable explanation is that the result, as mentioned earlier, might owe to the difference between the average GDP per capita of each country and that of its major cities, and that the difference is not cross-sectionally proportional.

One-year increases in property prices appear positively correlated to proxy rental yields in a similar manner across European cities. Proxy rental yields appear to respond in a similar manner to previous medium-term movements in property prices, but the sign is now reversed. Past medium-term increases in prices seem to lead to lower yields, while past medium-term decreases in prices seem to lead to increases in yields. Since we have estimated surrogate returns based on one-year price changes, it is possible that the reversal in the sign of the coefficients stems from the apparent medium-term reversal in price trends. 


\section{Tentative conclusions}

We conducted an exploratory analysis of the determinants of cross-sectional proxy returns and proxy rental yields in residential real estate. Asset pricing models predict that the expected returns of any risky asset should exhibit some sensitivity to one or several fundamental variables that represent a common source of undiversifiable risk. Residential real estate, just like works of art and collectibles, is unique because it represents both an investment vehicle and a durable consumption good. Its pricing and returns should thus reflect both the benefits from portfolio diversification and the effect of supply and demand.

In this paper, we explored the variation in proxy returns and proxy rental yields across 34 major European cities using a handful of independent variables that account for the influence of market risk, inflation, and liquidity. Given the small number of observation and the nature of the panel data analysis, we set out with very low expectations. In spite of major limitations in our data and in the definition of variables, our results appear remarkable in more than one way.

First, we concur with other studies and find that real estate markets, supposedly very segmented, respond to the same structural risk factors. This relationship predicted by asset pricing models must be extremely robust since our results have been obtained even with a very small sample, with crude proxies for many variables, and with several model specifications.

Second, it appears that Eastern European cities are quite different from Western European ones when it comes to wealth, inflation, and ownership rates. Proxy rental yields and ownership rates tend to be higher in the relatively poorer cities of Eastern Europe, while going down in the wealthier ones.

Third, although our model has a high explanatory power, the direction of the relationship among several variables is not consistent with the asset pricing theory. This finding requires several qualifications.

We are able to explain up to $70 \%$ in the cross-sectional variation in proxy returns and proxy rental yields, but some of the regression coefficients have unexpected signs. Most specifically, we are puzzled by the relationship between yields and GDP per capita, and yields and property size. We could speculate, more or less credibly, that in countries where a larger proportion of individuals have a higher income, the price of real estate will be pushed upwards, other things held constant. In poorer countries, the prices of properties would be relatively depressed due to insufficient purchasing power. While this hypothesis makes a lot of sense, it does not square well with the remainder of the data. We notice that one does not observe a high percent of home ownership in wealthier countries and a low percentage of home ownership in the more impoverished ones, as expected. In fact, the opposite is true. The poorer countries of Eastern Europe exhibit a much higher proportion of home ownership, while wealthier countries such as Germany show a much lower figure. In fact, home ownership is so strongly correlated with GDP per capita that fearful of the multicollinearity it would cause, we have chosen not to include it in our regression model. 
Thus, it is not clear at his point if the relationship between proxy rental yields and GDP per capita is just mediating the effect of homeownership rates, or is simply showing that poorer countries, where individuals have a much larger proportion of their wealth invested in residential real estate than in stocks and bonds, are more vulnerable to bubbles. There is, however, no significant difference in short- and medium-term price changes between Eastern and Western Europe.

In all honesty, we cannot fully explain or interpret all of our results in the framework offered by asset price models and rational expectations. It is quite possible that, in the worst case scenario, some of the more puzzling results are caused by a mismatch in the level of aggregation of our data, and the crude manner in which we have calculated rental yields and rental returns. Or, in the best case scenario, we would need to invoke behavioral factors, such as the endowment effect and social status bias.

\section{References}

BAKER, M.; WURGLER, J. (2007). Investor Sentiment in the Stock Market. Journal of Economic Perspectives, American Economic Association, vol. 21(2), pages 129-1. DOI: $\underline{10.1257 / \text { jep.21.2.129 }}$

BALL, M.; LIZIERI, C.; \& MACGREGOR, B.D. (1998). The Economics of Commercial Property Markets. Routledge, London.

BARBERIS, N.; SHLEIFER, A.; \& VISHNY, R. (1998). A Model of Investor Sentiment, Journal of Financial Economics, 49, 3, 307-343.

BOKHARI, S.; GELTNER, D. (2011) Loss Aversion and Anchoring in Commercial Real Estate Pricing: Empirical Evidence and Price Index Implications. Real Estate Economics 39.4: 635-670. DOI: 10.1111/j.1540-6229.2011.00308.X

BRUNNERMEIER, M. K.; JULLIARD, C.; (2008). Money Illusion and Housing Frenzies. The Review of Financial Studies 21 (1): 135-180. DOI: 10.1093/rfs/hhm043

BURMEISTER, E.; WALL, K. D. (1986). The arbitrage pricing theory and macroeconomic factor measures. Financial Review 21 (1): 1-2.

CASE, K. E.; SHILLER, R. J. (1988). The Behavior of Home Prices in Boom and Post Boom Markets, New England Economic Review, November, pp. 29-46.

COLLIERS REPORT: http://www.colliers.com/en-us/-/media/files/global/pdf/colliersinternational-2015-giss-report

DHAR, R.; GOETZMANN, W. (2005). Institutional perspectives on real estate investing: The role of risk and uncertainty (No. ysm457). Yale School of Management.

DUBBEN, N.; SAYCE, S. (1991). Property portfolio management: an introduction (pp. 128-58). London: Routledge.

EICHHOLTZ, P.; YÖNDER, E. (2015). CEO Overconfidence, REIT Investment Activity and Performance. Real Estate Economics, 43: 139-162. DOI: 10.1111/1540$\underline{6229.12054}$ 
EPSTEIN, L. G.; SCHNEIDER, M. (2002). Learning Under Ambiguity. Available at SSRN: http://ssrn.com/abstract=344920, DOI: $\underline{10.2139 / \text { ssrn.344920 }}$

EUROSTAT: Distribution of population by tenure status, type of household and income group http://www.statista.com/statistics/246355/home-ownership-rate-in-europe/

FARLOW, A. (2004). The UK Housing Market: Bubbles and Buyers. Paper presented at the Credit Suisse First Boston Housing Market Conference.

GENESOVE, D.; MAYER, C. (2001). Loss Aversion and Seller Behavior: Evidence from the Housing Market. Quarterly Journal of Economics 116(4), 1233-1260. DOI: $\underline{10.1162 / 003355301753265561}$

HARGREAVES, B. (2005). Exploring the yields on residential investment property. Pacific Rim Real Estate Society (PRRES).

HUNGRIA-GARCIA, R., LIND, H., \& KARLSSON, B. (2004). Property yields as tools for valuation and analysis. Report No. 52. Royal Institute of Technology, Stockholm.

KNOLL, K.; SCHULARICK, M.; \& STEGER T. (2014). No Price Like Home: Global House Prices, 1870-2012, CEPR Discussion Paper No. 10166.

MALPEZZI, S. (2003). Hedonic pricing models: A selective and applied review. Section in Housing Economics and Public Policy: Essays in Honor of Duncan Maclennan.

MODIGLIANI, F.; BRUMBERG, R. (1954) Utility Analysis and the Consumption Function. In Post-Keynesian Economics. Edited by K. Kurihara. New Brunswick, N.J.: Rutgers University Press, 1954. Pages 338-436.

ROLL, R.; ROSS, S. (1980). An empirical investigation of the arbitrage pricing theory. Journal of Finance 35 (5): 1073-1103.

ROSS, S. (1976). The arbitrage theory of capital asset pricing. Journal of Economic Theory 13 (3): 341-360.

SHILLER, R. J. (2008). Historic turning points in real estate. Eastern Economic Journal, 34(1), 1-13. DOI: $10.1057 /$ palgrave.eej.9050001

SIRMANS, S. G.; MACPHERSON, D. A.; \& ZIETZ, E. N. (2005). The composition of hedonic pricing models. Journal of real estate literature, 13(1), 1-44.

WALDEN, J. (2004). Real Investments under Knightian Uncertainty. Yale ICF Working Paper No. 04-08. Available at SSRN: http://ssrn.com/abstract=509643

WANG, K.; ZHOU, Y.; CHAN, S. H.; \& CHAU, K. W. (2000). Over-confidence and cycles in real estate markets: cases in Hong Kong and Asia. International Real Estate Review, 3(1), 93-108. 


\section{Appendix}

Table 1 Sample selection

\begin{tabular}{|c|c|c|c|c|c|c|}
\hline Country & City & $\begin{array}{l}\text { No. of ob- } \\
\text { servations }\end{array}$ & $\begin{array}{l}\text { GDP per } \\
\text { capita } \\
\text { (2013) }\end{array}$ & $\begin{array}{l}\text { Home own- } \\
\text { ership } \\
\text { (2013) }\end{array}$ & $\begin{array}{c}\text { One-year } \\
\text { price } \\
\text { change }\end{array}$ & $\begin{array}{l}\text { Five-year } \\
\text { price } \\
\text { change }\end{array}$ \\
\hline France & Paris & 4 & $\$ 42,503$ & $64.3 \%$ & $-1.31 \%$ & $8.2 \%$ \\
\hline Switzerland & $\begin{array}{r}\text { Geneva } \\
\text { Zurich }\end{array}$ & $\begin{array}{l}4 \\
1\end{array}$ & $\$ 84,815$ & $44 \%$ & $1.48 \%$ & $13.32 \%$ \\
\hline UK & London & 8 & $\$ 41,787$ & $64.6 \%$ & $9.01 \%$ & $16.84 \%$ \\
\hline Malta & $\begin{array}{l}\text { LaValetta } \\
\text { and surroundings }\end{array}$ & 3 & $\$ 22,780$ & $80.3 \%$ & $8.92 \%$ & $10.74 \%$ \\
\hline Germany & $\begin{array}{r}\text { Berlin } \\
\text { Frankfurt } \\
\text { Munich }\end{array}$ & $\begin{array}{l}4 \\
3 \\
4\end{array}$ & $\$ 46,269$ & $52.6 \%$ & $3.11 \%$ & $22.99 \%$ \\
\hline Austria & $\begin{array}{r}\text { Wien } \\
\text { Salzburg } \\
\text { Graz }\end{array}$ & $\begin{array}{l}7 \\
3 \\
3\end{array}$ & $\$ 50,547$ & $57.3 \%$ & $5.77 \%$ & $53.33 \%$ \\
\hline Greece & $\begin{array}{r}\text { Athens } \\
\text { Crete }\end{array}$ & $\begin{array}{l}6 \\
3\end{array}$ & $\$ 21,956$ & $75.8 \%$ & $-9.04 \%$ & $-35.66 \%$ \\
\hline Italy & $\begin{array}{r}\text { Rome } \\
\text { Milan }\end{array}$ & $\begin{array}{l}9 \\
4\end{array}$ & $\$ 35,926$ & $73 \%$ & $-4.85 \%$ & $-12.33 \%$ \\
\hline Romania (EE) & Bucharest & 3 & $\$ 9,499$ & $95.6 \%$ & & \\
\hline Spain & $\begin{array}{r}\text { Barcelona } \\
\text { Madrid }\end{array}$ & $\begin{array}{l}4 \\
6\end{array}$ & $\$ 29,863$ & $77.7 \%$ & $-2.89 \%$ & $-24.03 \%$ \\
\hline Czech Republic (EE) & Prague & 4 & $\$ 19,845$ & $80.1 \%$ & $4.62 \%$ & $-1.36 \%$ \\
\hline Portugal & $\begin{array}{r}\text { Algarve } \\
\text { Lisbon }\end{array}$ & $\begin{array}{l}3 \\
5\end{array}$ & $\$ 21,733$ & $74.2 \%$ & $1.48 \%$ & $-10.13 \%$ \\
\hline Bulgaria (EE) & Sofia & 10 & $\$ 7,499$ & $85.7 \%$ & $0.43 \%$ & $-14.95 \%$ \\
\hline Finland & Helsinki & 3 & $\$ 49,147$ & $73.6 \%$ & $-1.06 \%$ & $12.8 \%$ \\
\hline Estonia (EE) & Tallinn & 3 & $\$ 18,783$ & $81.1 \%$ & $14.68 \%$ & $86.8 \%$ \\
\hline Serbia (EE) & $\begin{array}{l}\text { Novi Beograd } \\
\text { Savski Venac }\end{array}$ & $\begin{array}{l}4 \\
3\end{array}$ & $\$ 6,354$ & $81.1 \%$ & $-4.12 \%$ & $12.36 \%$ \\
\hline Slovenia (EE) & Ljubljana & 4 & $\$ 23,289$ & $76.6 \%$ & $-11.3 \%$ & $-19.68 \%$ \\
\hline Latvia (EE) & Riga & 6 & $\$ 15,375$ & $81.2 \%$ & $5.78 \%$ & $31.62 \%$ \\
\hline Belgium & Brussels & 5 & $\$ 46,878$ & $72.3 \%$ & $-0.22 \%$ & $16.47 \%$ \\
\hline Poland (EE) & Warsaw & 7 & $\$ 13,648$ & $83.8 \%$ & $3.85 \%$ & $-4.93 \%$ \\
\hline Hungary (EE) & Budapest & 7 & $\$ 13,481$ & $89.6 \%$ & $1.38 \%$ & $-18.91 \%$ \\
\hline Slovakia (EE) & Bratislava & 4 & $\$ 18,047$ & $90.5 \%$ & $-0.41 \%$ & $-8.09 \%$ \\
\hline Lithuania (EE) & Vilnius & 6 & $\$ 15,538$ & $92.2 \%$ & $4.26 \%$ & $-2.58 \%$ \\
\hline Croatia (EE) & Zagreb & 3 & $\$ 13,608$ & $88.5 \%$ & $2.45 \%$ & $-24.19 \%$ \\
\hline Total observations & & 156 & & & & \\
\hline
\end{tabular}


Table 2 Sample statistics

\begin{tabular}{lrrrrr}
\hline Variable & Minimum & Median & Mean & Maximum & Std. Dev. \\
\hline Tax on rental income (\%) & $0.00 \%$ & $15.82 \%$ & $15.89 \%$ & $48.56 \%$ & $11.10 \%$ \\
\hline Area (square meters) & 35.0 & 85.00 & 102.20 & 250.0 & 52.94 \\
Consumer Price Index (\%) & $-0.70 \%$ & $7.70 \%$ & $8.42 \%$ & $28.50 \%$ & $5.02 \%$ \\
\hline Transaction costs (\%) & $3.45 \%$ & $11.20 \%$ & $10.66 \%$ & $21.10 \%$ & $4.32 \%$ \\
\hline GDP/capita (\$ 000) & $\$ 6.354$ & $\$ 22.78$ & $\$ 29.15$ & $\$ 84.82$ & $\$ 17.64$ \\
\hline Population (millions) & 0.039 & 1.195 & 1.769 & 7.074 & 1.688 \\
\hline Ownership rate (\%) & $44.00 \%$ & $75.80 \%$ & $74.40 \%$ & $95.60 \%$ & $12.54 \%$ \\
\hline One-year price change & $-11.3 \%$ & $1.38 \%$ & $0.77 \%$ & $14.68 \%$ & $5.35 \%$ \\
\hline Five-year price change & $-41.39 \%$ & $-3.76 \%$ & $2.71 \%$ & $86.80 \%$ & $26.71 \%$ \\
Yield (\%) & $1.78 \%$ & $4.55 \%$ & $4.62 \%$ & $8.30 \%$ & $1.26 \%$ \\
\hline After-tax yield (\%) & $1.17 \%$ & $3.72 \%$ & $3.91 \%$ & $6.83 \%$ & $1.21 \%$ \\
\hline Return & $-7.59 \%$ & $4.99 \%$ & $4.68 \%$ & $19.46 \%$ & $5.46 \%$ \\
\hline
\end{tabular}

Table 3 Comparative analysis of the sample statistics: Eastern vs. Western Europe

\begin{tabular}{|c|c|c|c|c|c|c|c|}
\hline & \multicolumn{3}{|c|}{ Eastern Europe } & \multicolumn{3}{|c|}{ Western Europe } & \multirow{2}{*}{$\begin{array}{c}\text { T-statistic } \\
\text { for means } \\
\text { (unequal } \\
\text { samples) }\end{array}$} \\
\hline & Mean & Median & $\begin{array}{l}\text { Standard } \\
\text { Deviation }\end{array}$ & Mean & Median & $\begin{array}{l}\text { Standard } \\
\text { Deviation }\end{array}$ & \\
\hline Area & 94.22 & 80.00 & 46,80 & 107.7 & 90.0 & 56.40 & -1.6273 \\
\hline $\mathrm{CPI}$ & $11.11 \%$ & $8,50 \%$ & $6.45 \%$ & $6.55 \%$ & $7.20 \%$ & $2.34 \%$ & $5.4243^{* *}$ \\
\hline Transaction costs & $7.104 \%$ & $6.73 \%$ & $2.40 \%$ & $13.14 \%$ & $12.75 \%$ & $3.56 \%$ & -12.6544 ** \\
\hline GDP per capita & 13.52 & 13.65 & 4.92 & 40.02 & 41.79 & 14.90 & -15.8668 ** \\
\hline Population & 1.663 & 1.193 & 1.40 & 1.84 & 1.25 & 1.87 & -0.6912 \\
\hline Ownership & $85.36 \%$ & $85.70 \%$ & $5.00 \%$ & $66.77 \%$ & $72.65 \%$ & $10.35 \%$ & 14.9124 ** \\
\hline $\begin{array}{l}\text { One-year changes } \\
\text { in price }\end{array}$ & $1.18 \%$ & $1.38 \%$ & $5.42 \%$ & $0.48 \%$ & $1.48 \%$ & $5.31 \%$ & 0.7964 \\
\hline $\begin{array}{l}\text { Five-year change } \\
\text { price }\end{array}$ & $-1.70 \%$ & $-4.93 \%$ & $26.17 \%$ & $5.77 \%$ & $10.74 \%$ & $26.80 \%$ & -1.7348 \\
\hline Rental yields & $5.64 \%$ & $5.54 \%$ & $1.02 \%$ & $3.91 \%$ & $3.85 \%$ & $0.85 \%$ & $11.1155^{* *}$ \\
\hline $\begin{array}{l}\text { After tax rental } \\
\text { yields }\end{array}$ & $4.97 \%$ & $4.90 \%$ & $1.21 \%$ & $3.17 \%$ & $3.10 \%$ & $0.84 \%$ & $13.5245^{* *}$ \\
\hline Returns & $6.819 \%$ & $8.15 \%$ & $5.51 \%$ & $4.40 \%$ & $4.741 \%$ & $5.25 \%$ & $2.7575^{* *}$ \\
\hline
\end{tabular}


Table 4 The Matrix of Correlations among the Sample Variables

\begin{tabular}{|c|c|c|c|c|c|c|c|c|c|c|c|}
\hline & $\frac{0}{\frac{0}{2}}$ & $\stackrel{\mathbb{J}}{\stackrel{\mathbb{\varpi}}{\overparen{D}}}$ & 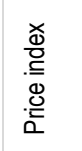 & 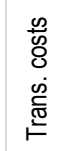 & 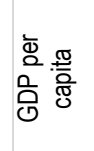 & 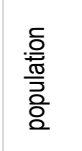 & 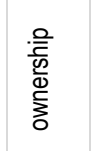 & 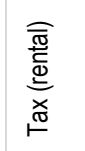 & 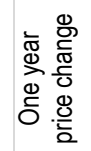 & 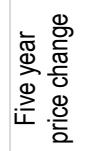 & 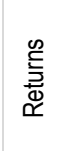 \\
\hline yield & 1 & & & & & & & & & & \\
\hline area & -0.373 & 1 & & & & & & & & & \\
\hline price index & 0.403 & -0.107 & 1 & & & & & & & & \\
\hline transaction.costs & -0.317 & 0.130 & -0.313 & 1 & & & & & & & \\
\hline GDP per capita & -0.594 & 0.073 & -0.494 & 0.287 & 1 & & & & & & \\
\hline population & -0.114 & 0.096 & 0.001 & -0.104 & 0.039 & 1 & & & & & \\
\hline ownership & 0.634 & -0.047 & 0.379 & -0.263 & -0.895 & 0.059 & 1 & & & & \\
\hline tax rental & -0.173 & 0.014 & -0.124 & 0.080 & 0.590 & -0.348 & -0.499 & 1 & & & \\
\hline One-year price change & -0.019 & -0.017 & -0.021 & 0.322 & 0.160 & 0.245 & -0.189 & 0.011 & 1 & & \\
\hline Five-year price change & -0.207 & -0.080 & 0.093 & -0.199 & 0.437 & -0.093 & -0.522 & 0.292 & 0.715 & 1 & \\
\hline Returns & 0.188 & -0.089 & 0.063 & -0.388 & -0.005 & 0.243 & -0.021 & -0.103 & 0.975 & 0.638 & 1 \\
\hline
\end{tabular}

Table 5 Regression results: Total returns dependent variable

\begin{tabular}{|c|c|c|c|c|}
\hline & 1(a). Returns & $\begin{array}{c}\text { 1(b). Returns } \\
\text { (After-tax yields) }\end{array}$ & 1(c). Returns & $\begin{array}{c}\text { 1(d). Returns } \\
\text { (After-tax yields) }\end{array}$ \\
\hline $\begin{array}{l}\text { Intercept } \\
\text { (std. dev.) } \\
\text { (t-statistic) }\end{array}$ & $\begin{array}{c}(12.069) \\
(1.255) \\
(9.618)^{\star \star \star}\end{array}$ & $\begin{array}{c}12.029 \\
(1.221) \\
(9.847)^{\star \star \star}\end{array}$ & $\begin{array}{c}9.001 \\
(2.220) \\
(4.054)^{\star \star \star}\end{array}$ & $\begin{array}{c}9.147 \\
(2.176) \\
(4.204)^{\star \star \star}\end{array}$ \\
\hline $\begin{array}{l}\text { Area } \\
\text { (std. dev.) } \\
\text { (t-statistic) }\end{array}$ & $\begin{array}{l}-0.005 \\
(0.005) \\
(-0.957)\end{array}$ & $\begin{array}{l}-0.003 \\
(0.005) \\
(-0.641)\end{array}$ & $\begin{array}{l}-0.005 \\
(0.005) \\
(-0.935)\end{array}$ & $\begin{array}{l}-0.003 \\
(0.005) \\
(-0.622)\end{array}$ \\
\hline $\begin{array}{l}\text { CPI } \\
\text { (std. dev.) } \\
\text { (t-statistic) }\end{array}$ & $\begin{array}{c}-0.381 \\
(0.067) \\
(-5.722)^{* * *}\end{array}$ & $\begin{array}{c}-0.361 \\
(0.062) \\
(-5.829)^{* * *}\end{array}$ & $\begin{array}{c}-0.376 \\
(0.066) \\
(-5.682)^{* * *}\end{array}$ & $\begin{array}{c}-0.359 \\
(0.062) \\
(-5.819)^{* * *}\end{array}$ \\
\hline $\begin{array}{l}\text { GGP/capita } \\
\text { (std. dev.) } \\
\text { (t-statistic) }\end{array}$ & $\begin{array}{c}-0.202 \\
(0.030) \\
(-7.153)^{\star * *}\end{array}$ & $\begin{array}{c}-0.170 \\
(0.020) \\
(-8.154)^{\star * *}\end{array}$ & $\begin{array}{c}-0.168 \\
0.035 \\
(-4.842)^{\star \star *}\end{array}$ & $\begin{array}{c}-0.140 \\
(0.028) \\
(-4.984)^{\star \star *}\end{array}$ \\
\hline $\begin{array}{l}\text { Population } \\
\text { (std. dev.) } \\
\text { (t-statistic) }\end{array}$ & $\begin{array}{c}1.247 \\
(0.181) \\
(6.899)^{\star * \star}\end{array}$ & $\begin{array}{c}1.107 \\
(0.151) \\
(7.323)^{\star \star \star}\end{array}$ & $\begin{array}{c}1.284 \\
(0.181) \\
(7.093)^{\star \star \star}\end{array}$ & $\begin{array}{c}1.150 \\
(0.153) \\
(7.528)^{\star * \star}\end{array}$ \\
\hline $\begin{array}{l}\text { Transaction costs } \\
\text { (std. dev.) } \\
\text { (t-statistic) }\end{array}$ & $\begin{array}{c}-0.1182 \\
(0.069) \\
(-1.718)^{*}\end{array}$ & $\begin{array}{c}-0.1425 \\
(0.066) \\
(-2.163)^{\star *}\end{array}$ & $\begin{array}{l}-0.0035 \\
(0.097) \\
(-0.036)\end{array}$ & $\begin{array}{l}-0.034 \\
(0.094) \\
(-0.358)\end{array}$ \\
\hline $\begin{array}{l}\text { Tax on rental income } \\
\text { (std. dev.) } \\
\text { (t-statistic) }\end{array}$ & $\begin{array}{c}0.090 \\
0.034 \\
(2.631)^{* * *}\end{array}$ & - & $\begin{array}{c}0.086 \\
(0.034) \\
(2.541)^{\star \star}\end{array}$ & 150,1 \\
\hline $\begin{array}{l}\text { Five-year change in price } \\
\text { (std. dev.) } \\
\text { (t-statistic) }\end{array}$ & $\begin{array}{c}0.19 \\
(0.012) \\
(15.088)^{\star \star \star}\end{array}$ & $\begin{array}{c}0.187 \\
(0.012) \\
(15.465)^{\star \star \star}\end{array}$ & $\begin{array}{c}0.190 \\
(0.013) \\
(15.121)^{\star * *}\end{array}$ & $\begin{array}{c}0.187 \\
(0.012) \\
(15.514)^{\star \star \star}\end{array}$ \\
\hline $\begin{array}{l}\text { Dummy for EE } \\
\text { (std. dev.) } \\
\text { (t-statistic) }\end{array}$ & & - & $\begin{array}{c}1.925 \\
(1.153) \\
(1.671)^{\star} \\
\end{array}$ & $\begin{array}{c}1.80 \\
(1.128) \\
(1.597)^{\star} \\
\end{array}$ \\
\hline Adjusted R-square & 0.6709 & 0.683 & 0.6748 & 0.6863 \\
\hline F-statistic & $46.14^{\star * \star}$ & $56.66^{\star \star \star}$ & $41.21^{\star \star \star}$ & $49.43^{\star \star \star}$ \\
\hline
\end{tabular}

*** coefficient significant at the $1 \%$ level

** coefficient significant at the $5 \%$ level

* coefficient significant at the $10 \%$ level 
